\title{
Potency of Stirred Microfiltration Cell in Separation of Fermented Beans as Protein Isolate for Natural Source of Folic Acid
}

\author{
Aspiyanto $^{1, *}$, Agustine Susilowati ${ }^{2}$, Puspa Dewi Lotulung ${ }^{2}$, Hakiki Melanie ${ }^{2}$, and Yati Maryati ${ }^{2}$ \\ Research Center for Chemistry - Indonesian Institute of Sciences, Kawasan PUSPIPTEK, \\ Serpong - 15314, South Tangerang, Banten, Indonesia
}

\section{${ }^{*}$ Corresponding author:}

email:aspiyanto_2010@yahoo.com

Received: May 22, 2017

Accepted: October 9, 2017

DOI: $10.22146 / \mathrm{ijc} .25164$

\begin{abstract}
Protein isolate from fermented soybean (Glycine soja L.), fermented mung bean (Phaseolus radiatus L.) and fermented kidney bean (Phaseolus vulgaris L.) tempeh are a natural source of folic acid with the main role in brain smartness. Microfiltration (MF) membrane $(0.15 \mu \mathrm{m})$ fitted in dead-end stirred microfiltration cell (SMFC) was able to separate protein isolate from three (3) kinds of tempeh at stirrer rotation speed $400 \mathrm{rpm}$, room temperature and pressure 40 Psi for $30 \mathrm{~min}$. The result of experimental work showed that SMFC having potential use in separation of protein isolate were affected by types of bean and membrane performance on isolate composition in the retentate and permeate. SMFC was able to retain better protein isolate in retentate than that passing across permeate. Retentate of protein isolate from soybean tempeh, mung bean tempeh, and kidney bean tempeh had subsequently compositions of folic acid 362.07, 254.07 and $506.07 \mu \mathrm{g} / \mathrm{mL}$, total solids 5.56, 4.08 and $1.82 \%$, N-amino 4.34, 3.36 and $0.56 \mathrm{mg} / \mathrm{mL}$, and dissolved protein $0.79,0.34$ and $0.72 \mathrm{mg} / \mathrm{mL}$. In this process condition, SMFC was able to increase folic acid in protein isolate retentate of soy tempeh of 59.67\% (0.59 times), mung bean tempeh of 1.104.58\% (1.1 times) and kidney bean tempeh of 142.67\% (1.42 times) before purification process in the retentate. Based on both SMFC performance and efficiency, all the best purification optimization were obtained kidney beans tempeh. Identification of monomer of kidney bean tempeh protein isolate gave monomers of folic acid, glutamic acid and folic acid fractionation with a molecular weight of 443.57, 148.16 and $221.21 \mathrm{Da}$. and relative intensity of $1.28,50.11$ and $7.05 \%$, respectively.
\end{abstract}

Keywords: stirred microfiltration cell (SMFC); folic acid; glutamic acid; tempeh; protein isolate

\section{- INTRODUCTION}

Separation and purification processes on fermented beans (tempeh) protein isolate through microfiltration (MF) membrane are an important effort to obtain folic acid, a protein derivative consisted of heterocyclic pteridine, p-aminobenzoic acid (PABA) and glutamic acid [1], which has an important role on brain smartness. Membrane-based separation and purification processes are selected since it refers to diameter size of the pores in the membrane and molecular size and shape of the particle. It can generally operate at room temperature, no need to add other chemical substances has lower consumption of energy related to the absence of change in phase or state of the solvent, and operates continuously [2] so that it will be suitable for folic acid keeping. MF membrane has pore sizes $0.1-10 \mu \mathrm{m}$ and thickness in the range of 10-12 $\mu \mathrm{m}$. Such MF membrane is able to separate dispersed particles (colloids, fat globules, cells) larger than $500.000 \mathrm{~g} / \mathrm{mol}$ (particles size $0.1-10 \mu \mathrm{m}$ ) [3]. This property is possibility suitable and reasonable for tempeh suspension that has sensitive property on denaturation due to a particle size of proteins (amino acids) in the range of $0.008-0.1 \mu \mathrm{m}$ [45]. Separation of folic acid through Stirred Microfiltration Cell (SMFC) mode in laboratory scale $(180 \mathrm{~mL})$ is an effort to know the characteristic of tempeh protein isolate applied toward larger scale

Aspiyanto et al. 
(module 9 L). SMFC is a separation mode using traditional and conventional way or centrifugation in which rotation speed has an important role [6-7]. Applying pressure is started from zero (0) due to gravity force acting to supplying nitrogen gas as driving force of fluid through membrane layer in order to result in retentate (concentrate) and permeate (extract). In this dead-end SMFC mode, use of magnetic stirrer will aid separation process to prevent fouling on the membrane surface. In this dead-end SMFC mode, feed fluid flows perpendicular to membrane surface with components concentrations rejected into feed fluid becoming more and more increase so that permeate quality decreases on process time. Kinds of tempeh protein isolate affect possibility on separation process because of material characteristic, particularly protein, type and size of MF membrane, operation condition (flow rate, pressure, time) [5]. Recovery of protein isolate concentrate can be directly used as fortificant on the product of smart food, particularly folic acid-based food products.

The goal of this experiment work was to produce and to find out characteristic and composition of folic acid in retentates of soybean tempeh, mung bean tempeh and kidney bean tempeh as a result of purification of fermented beans using MF membrane $(0.15 \mu \mathrm{m})$ fitted in SMFC under fixed operation condition (stirrer rotation speed $400 \mathrm{rpm}$, room temperature and pressure 40 Psi for $30 \mathrm{~min})$.

\section{- EXPERIMENTAL SECTION}

\section{Materials}

Main materials used in this experiment were distilled water, soybeans tempeh, mung beans tempeh, and kidney beans tempeh purchased in local market, inoculum mixture of Rhizopus sp. (P.T. AFI, Bandung), inoculum of Rhizopus oligosporus $\mathrm{C}_{1}$ (Research Center for Chemistry - LIPI), perforated plastic sheets (local), $0.15 \mu \mathrm{m}$ microfiltration (MF) membrane (Fluoropolymer, FSM0.15-PP, Alfa Laval, Denmark), standard folic acid, hydrochloric acid, sodium nitrite, sulfamic acid, aminophenol, acetic acid, methanol, sodium azide $\left(\mathrm{NaN}_{3}\right)$ solution and chemical reagents for dissolved protein and $\mathrm{N}$-amino determinations. All other chemical reagents were of analytical grade, and solutions were based on highly purified water (distilled water).

\section{Instrumentation}

Main equipments utilized in this experimental work were thermometer, $\mathrm{pH}$ meter, balance (Fujitsu, Japan), distilling unit (Gesellschaft fur Labortechnik GmbH/GFL, Type 2012, Germany), system of laminar flow chamber (local), incubator (local), series of fermentation system in laboratory scale (local), mixer, pulverizer or blender, sieve of 100 mesh (Retsch, Germany), stopwatch (Hanhart Profil 2, Germany), magnetic stirrer (HI $303 \mathrm{~N}$, HANNA Instrument, Japan), pressure gauge of technical nitrogen (Fisher Scientific Company, England), cylindrical tank for technical nitrogen (Local), Dead-End Stirred Ultrafiltration Cell (SUFC) (MILLIPORE, Model 8200, U.S.A.), aluminium plate (local), Oven (Memmert, Germany), Desiccator (NORMAX), UV-Vis Spectro photometer (Model RF-550, Shimadzu, Japan), and LCMS (Mariner Biospectrometry with LC (Hitachi L 6200) using C18 (RP 18) Supelco column.

\section{Procedure}

\section{Experimental design}

To initiate experimental activity, 1 (one) part of the soybeans tempeh was mixed with 1 (one) part of the distilled water $(1: 1, \mathrm{w} / \mathrm{v})$, pulverized and filtered through a $100 \mu \mathrm{m}$ sieve. The soybeans tempeh filtrate obtained was then microfiltered using $0.15 \mu \mathrm{m}$ membrane fitted in SMFC under fixed process condition (stirrer rotation speed $400 \mathrm{rpm}$, room temperature and pressure $40 \mathrm{Psi}$ for $30 \mathrm{~min}$ ) until it produces soybeans tempeh retentate and permeates. Same procedures and all process condition were performed for mung beans tempeh filtrate and kidney beans tempeh filtrate. Analyses on original material (feed), tempeh retentate (concentrate) and permeate as a result of microfiltration on soybeans tempeh, mung beans tempeh and kidney beans tempeh filtrates through $0.15 \mu \mathrm{m}$ membrane were performed on total solids (Gravimetric method), dissolved protein (Lowry method) [8], $\mathrm{N}$-amino (Copper method) [9] and folic acid (UV-vis spectrophotometry) [10]. Identification of folic acid was conducted by means of LC-MS 
(Mariner Biospectrometry) with LC (Hitachi L 6200) [11].

All the purification processes were repeated at least two times, and all the analyses were also determined in duplicate. Data processor was done according to a descriptive method based on average results of analyses. All the experiments were repeated three times.

\section{Fermentation process of beans (tempeh)}

A number of soybeans were subsequently sorted to choose uniform and good beans, washed, blanched for 30-45 min, cooled to room temperature and soaked in water overnight at $\mathrm{pH} 5$. At the end of this activity, soybeans were hulled, clean washed, allowed and inoculated by an inoculum of Rhizopus oligosporus $\mathrm{C}_{1}$ $(0.2 \%, \mathrm{w} / \mathrm{w})$ at $30^{\circ} \mathrm{C}$ for $72 \mathrm{~h}$. While, cleaned kidney beans was incubated by inoculum mixture of Rhizopus $(0.2 \%$, $\mathrm{w} / \mathrm{w}$ ) at $30^{\circ} \mathrm{C}$ for $72 \mathrm{~h}$. Three (3) kinds of fermented beans were covered with a perforated plastic sheet to reduce the evaporation rate until it is produced tempeh with the uniform growth of Rhizopus inoculum [12].

\section{Processes of pulverizing and separation of tempeh protein isolate through SMFC}

One part of tempeh from each kind of beans was mixed with 1 (one) part of the distilled water $(1: 1, \mathrm{w} / \mathrm{v})$, pulverized, and filtered through a $100 \mu \mathrm{m}$ sieve. The beans tempeh filtrate obtained was then diluted by adding 1 part of water until it is formed tempeh suspension. Tempeh suspension was further purified by passing it via $0.15 \mu \mathrm{m}$ MF membrane equipped in dead-end SMFC mode. The commercial $0.15 \mu \mathrm{m}$ MF membrane discs having a $0.15 \mu \mathrm{m}$ of pore diameter size with the glossy skin side toward a solution was placed into the dead-end SMFC mode connected to a nitrogen gas cylinder. Prior to use, membranes were rinsed with RO water. A dead-end SMFC of $180 \mathrm{~mL}$ capacity and a membrane area of $30.175 \mathrm{~cm}^{2}$ [13]. Each MF membrane was first compacted at 40 psi for $5 \mathrm{~min}$. The solution of tempeh suspension was poured to the dead-end SMFC. Operation conditions were stirrer rotation speed $400 \mathrm{rpm}$, room temperature and trans-membrane pressure (TMP) 40 Psi for $30 \mathrm{~min}$. Volumetric permeate flow rate was measured after each $\mathrm{mL}$ of permeate collected. Samples of permeate were collected and recorded for $30 \mathrm{~min}$ to determine the permeate flux through the membrane. Permeate and retentate (concentrate) were regularly sampled for analysis of their folic acid, total solids, $\mathrm{N}$-amino and dissolved protein. After end use, the membrane was cleaned with RO water by filling the SMFC for $5 \mathrm{~min}$. Sodium azide $\left(\mathrm{NaN}_{3}\right)$ solution $(1 \mathrm{mg} / \mathrm{L})$ was added to prevent bacterial growth.

\section{Analysis of folic acid}

Analysis of folic acid was determined by using spectrophotometry according to the reaction between diazotization of $\mathrm{p}$-amino benzoyl glutamic acid yielded after reduction of folic acid and 3-aminophenol until it forms a yellow-orange complex. About $1 \mathrm{~mL}$ of standard folic acid or sample was added with $1 \mathrm{~mL}$ of $\mathrm{HCl}(4 \mathrm{M})$, $1 \mathrm{~mL}$ of sodium nitrite $(1 \%, \mathrm{w} / \mathrm{v}), 1 \mathrm{~mL}$ of sulfamic acid $(1 \%, \mathrm{w} / \mathrm{v})$ and $1 \mathrm{~mL}$ of 3 -aminophenol $(1 \%, \mathrm{w} / \mathrm{v})$, and vortexed until yellow-orange complex was formed. Further, the complex compound sample was measured its absorbance by means of UV-vis spectrophotometer at wavelength $460 \mathrm{~nm}$ [10].

\section{Identification of glutamic acid as tempeh protein isolate through LC-MS}

Beans tempeh extract samples $(20 \mu \mathrm{L})$ was injected in Liquid Chromatography (LC) system integrated with Q-tof Mass Spectrometer (MS) via Electro Spray Ionisation (ESI) system. Scan mode was conducted in a range of $\mathrm{m} / \mathrm{z} 100-1200$ and $140^{\circ} \mathrm{C}$. LC (Hitachi L 6200) uses C18 (RP 18) Supelco column with a column length of $250 \times 2 \mathrm{~mm}$ and particles size of $5 \mu \mathrm{m}$. Kinds of solvent were water containing $0.3 \%$ acetic acid (A) and methanol containing $0.3 \%$ acetic acid (B) at a ratio of 90 parts of methanol and 10 parts of water at flow rate of $1 \mathrm{~mL} / \mathrm{min}$ [11].

\section{- RESULTS AND DISCUSSION}

\section{Characteristic of Feed}

Tempeh suspensions as a result of pulverizing on soybeans tempeh, mung beans tempeh and kidney beans tempeh $(1: 1, \mathrm{w} / \mathrm{v})$ and filtration through 100 mesh sieve and diluting to $1: 2(\mathrm{w} / \mathrm{v})$ were showed in Fig. 1a-c, respectively. Based on their compositions, soybeans tempeh suspension when compared to mung beans tempeh and kidney beans tempeh suspensions were 
summarized in Table 1. The difference in these compositions is not only caused by kinds of beans, but also tempeh characteristics after the fermentation process. Soybeans tempeh had been fulfilled by miselia. While, mung beans tempeh and kidney beans tempeh had been fulfilled by miselia with the dense condition, but bean seeds on tempeh were still dominant [12]. The process of pulverizing on soybeans tempeh, mung beans tempeh and kidney beans tempeh $(1: 1, \mathrm{w} / \mathrm{v})$ and filtration through 100 mesh sieve and diluting to $1: 2(\mathrm{w} / \mathrm{v})$ affect possibility on the whole feed compositions.

\section{Effect of Purification Process on Composition of Tempeh Isolate}

Feed type of kidney beans tempeh extract as a result of pulverizing at a 1:2 ratio of kidney beans tempeh extract to water, type of retentate from protein isolate of soybeans tempeh, and type of permeate from protein isolate of soybeans tempeh as a result of purification of tempeh extract via $0.15 \mu \mathrm{m}$ of MF membrane were shown Fig. 1a-c, respectively. While, recovery of folic acid, total solid, $\mathrm{N}$-amino, and dissolved protein in the retentate and permeate as a result of purification of kidney bean

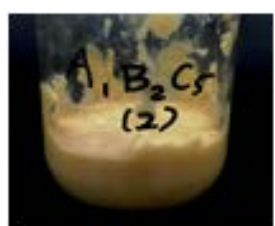

(a)

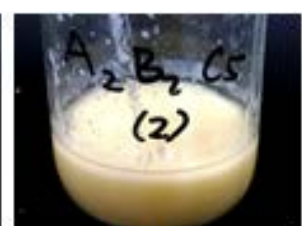

(b)

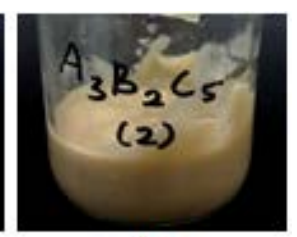

(c)
Fig 1. Soy beans tempeh suspension (a), mung beans tempeh suspension (b) and kidney beans tempeh suspension (c) as feed-in purifying process using deadend SMFC mode

Table 1. Compositions of tempeh suspension introduced as feed in purifying folic acid by means of $0.15 \mu \mathrm{m}$ MF membrane fitted in SMFC

\begin{tabular}{lcccc}
\hline \multirow{2}{*}{$\begin{array}{c}\text { Kinds of tempeh } \\
\text { suspension }\end{array}$} & Total solids (\%) & $\begin{array}{c}\text { Dissolved } \\
\text { protein }(\%)\end{array}$ & $\begin{array}{c}\text { N-amino } \\
(\mathrm{mg} / \mathrm{mL})\end{array}$ & $\begin{array}{c}\text { Folic acid } \\
(\mu \mathrm{g} / \mathrm{mL})\end{array}$ \\
\cline { 2 - 5 } & 5.70 & 0.78 & 3.78 & 606.74 \\
Soy beans & 3.87 & 0.75 & 2.24 & 242.93 \\
Mung beans & 1.33 & 0.76 & 0.42 & 354.71 \\
Kidney beans & & & & \\
\hline
\end{tabular}
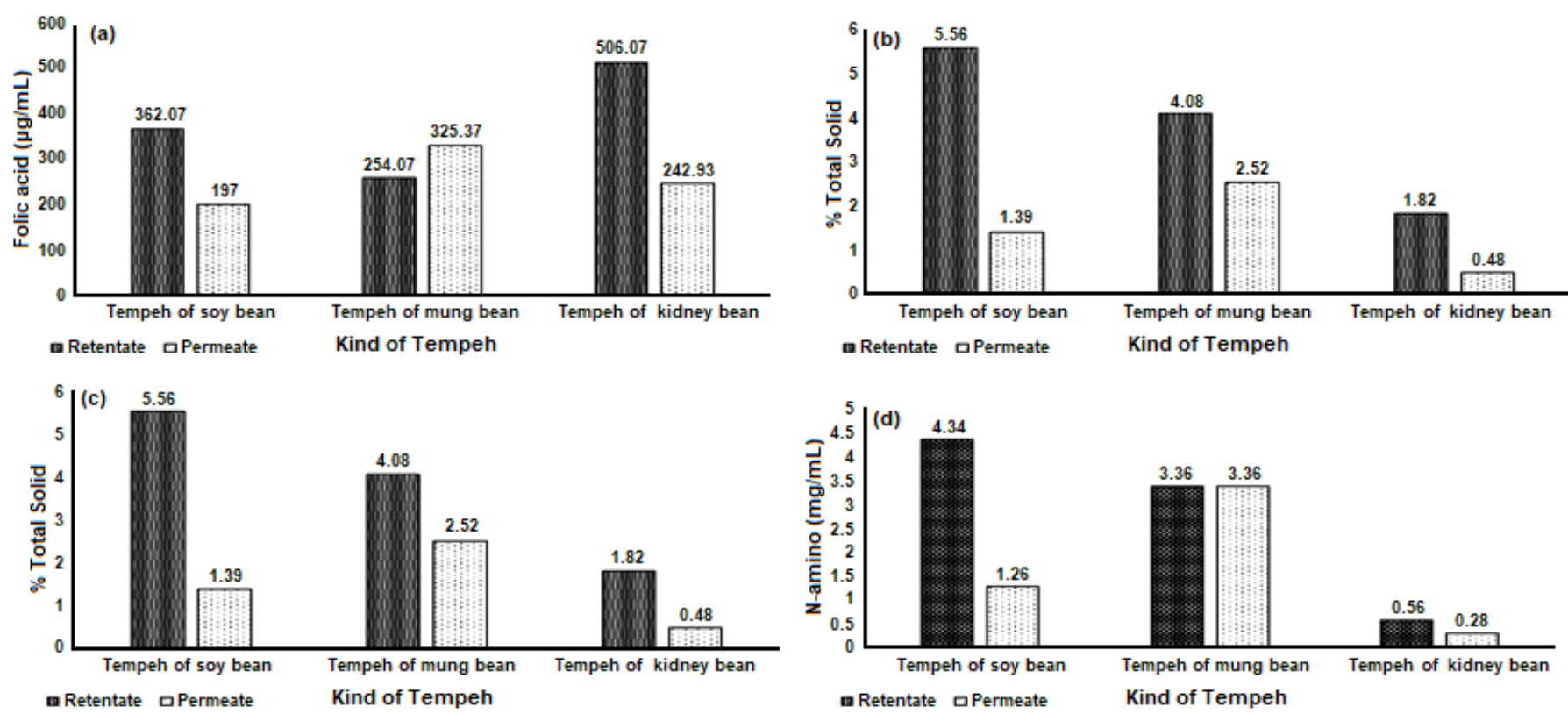

Fig 2. Recovery of (a) folic acid, (b) total solid, (c) N-amino and (d) dissolved protein in the retentate and permeate as a result of purification of kidney bean tempeh extract via $0.15 \mu \mathrm{m}$ of MF membrane 


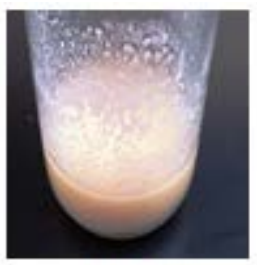

(a)

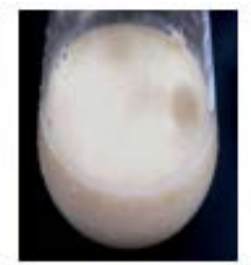

(b)

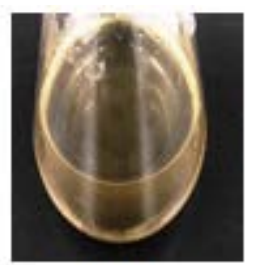

(c)
Fig 3. (a) feed, (b) type of retentate (concentrate) and (c) type of permeate from protein isolate of soybeans tempeh as a result of purification of tempeh extract via $0.15 \mu \mathrm{m}$ of MF membrane

tempeh extract via $0.15 \mu \mathrm{m}$ of MF membrane were shown in Fig. 2a-d.

\section{Folic acid}

The purification process of tempeh suspension through $0.15 \mu \mathrm{m}$ MF membrane fitted in SMFC gave various separation of folic acid for each kind of tempeh. The particle size of folic acid predicted between 0.008$0.1 \mu \mathrm{m}$ [4] or 0.001-0.1 $\mu \mathrm{m}$ [14] should pass more much folic acid in permeate. On the other hand, at a condition is occurred 'fouling', namely a phenomenon in which the membrane interacts or absorbs components in the feed fluid [3], generating in a drop in membrane performance (declining of the flux and/or raise in rejection of components). This is usually an irreversible and time dependent phenomenon, which differs it from concentration polarization [5]. Fouling is caused by interaction among components, the interaction between component and membrane, and operation conditions, such as tempeh, pressure, stirrer rotation speed, temperature and time.

MF membrane retains folic acid of soybeans tempeh $(362.07 \mu \mathrm{g} / \mathrm{mL})$ and folic acid of kidney beans tempeh $(506.07 \mu \mathrm{g} / \mathrm{mL})$ higher than in permeate 197 and $242.93 \mu \mathrm{g} / \mathrm{mL}$. A different trend was indicated for mung beans tempeh, in which folic acid in permeate passes more much $(325.37 \mu \mathrm{g} / \mathrm{mL})$ than in retentate $(254.07 \mu \mathrm{g} / \mathrm{mL})$ (Fig. 2a). Based on recovery of folic acid, SMFC method was able to raise folic acid in retentates of soybeans tempeh of $59.67 \%$ ( 0.59 folds), mung beans tempeh of $1,104.58 \%$ ( 11 folds) and kidney beans tempeh of $142.67 \%$ (1.42 folds) when compared to folic acid in feeds of $606.74,242.93$ and $354.71 \mu \mathrm{g} / \mathrm{mL}$, respectively. Whereas, based on membrane performance and process efficiency when compared to folic acid concentration in retentate and permeate, SMFC methods were able to separate folic acid of soybeans tempeh of $64.76 \%$ from retentate $(559.07 \mu \mathrm{g} / \mathrm{mL})$ and permeate $(362.07 \mu \mathrm{g} / \mathrm{mL})$, mung beans tempeh of $43.85 \%$ from retentate $(579.44 \mu \mathrm{g} / \mathrm{mL})$ and permeate $(254.07 \mu \mathrm{g} / \mathrm{mL})$, and kidney beans tempeh of $67.57 \%$ from retentate $(749 \mu \mathrm{g} / \mathrm{mL})$ and permeate $(506.07 \mu \mathrm{g} / \mathrm{mL})$, respectively. In both interpretations, optimization of folic acid in retentate was obtained by type of kidney beans tempeh. Recovery of folic acid in the retentate and permeate as a result of MF processes were not only caused by tempeh type, but also interaction between rotation force, temperature, pressure, and time.

\section{Total solids}

Purification and/or separation process of folic acid from fermented beans via $0.15 \mu \mathrm{m}$ of MF membrane equipped in SMFC mode under fixed condition indicated the separation of total solids for each kind of tempeh. Total solid is the whole components (protein, carbohydrate, fat, mineral) accumulated and a material dissolved into water. The difference in total solids in the retentate and permeate is possibly caused by more much components in tempeh having a particle size larger than $0.15 \mu \mathrm{m}$ so that they will be retained on the membrane surface. While components with size smaller $0.15 \mu \mathrm{m}$ will pass as permeate. Besides, it is occurred fouling during purification process because of decreasing water mass, in which water mass passing through the membrane was predicted approximately $30 \%$ of feed fluid [3]. Total solids for each tempeh isolate are different material relating to kinds of tempeh. Particles with size larger $0.2 \mu \mathrm{m}$, such as fat $(1-10 \mu \mathrm{m})$, protein $(0.04-2 \mu \mathrm{m})$ and sugars $(8-20 \mu \mathrm{m})$ were retained on the membrane surface, while flavor, aroma, taste-form compounds (smaller $0.04 \mu \mathrm{m})$, color pigment $(0.1-10 \mu \mathrm{m})$, monosaccharides (lactose) $(0.001 \mu \mathrm{m})$, and peptides (0.01-0.1 $\mu \mathrm{m})$ passed freely as permeate [5]. Based on recovery of total solids, SMFC method was able to increase total solids in retentates of soybeans tempeh of 97.54\% (0.97 folds), mung beans tempeh of $105.42 \%$ (1.05 folds) and kidney beans tempeh of 136\% (1.36 
folds) when compared to total solids in feeds of 5.7, 3.87 and $1.33 \%$, respectively. Whereas, based on membrane performance and process efficiency when compared to retentate and permeate, SMFC method was able to separate total solids in retentate from soybeans tempeh of $80 \%$, mung beans tempeh of $61.8 \%$ and kidney beans tempeh of $79 \%$, respectively. Total solids in retentates from soybeans tempeh of $6.95 \%$, mung beans tempeh of $6.66 \%$ and kidney beans tempeh of $2.3 \%$, and total solids in permeates from soybeans tempeh of $5.56 \%$, mung beans tempeh of $4.08 \%$ and kidney beans tempeh of $1.82 \%$, respectively.

\section{N-amino}

Amino acids as $\mathrm{N}$-amino is an important component from tempeh isolate because it is precursor compound to form savory taste, particularly L-glutamic. The purification process of tempeh extract through $0.15 \mu \mathrm{m}$ MF membrane produced successfully separation of $\mathrm{N}$-amino for each tempeh type. Particles size of amino acids ranging 0.01-0.1 $\mu \mathrm{m}$ [14] will pass freely in permeate as a result of purification process of tempeh extract through $0.15 \mu \mathrm{m}$ MF membrane, however, particles of amino acids were possibility retained on the membrane surface due to fouling during the process [5]. Based on recovery of $\mathrm{N}$-amino, SMFC mode was able to raise $\mathrm{N}$-amino in retentates of soybeans tempeh (114.81\% or 1.1 folds), mung beans tempeh ( $150 \%$ or 1.5 folds) and kidney beans tempeh ( $133 \%$ or 1.33 folds) when compared to $\mathrm{N}$-amino for feeds of soybeans (3.78\%), mung beans (2.24\%) and kidney beans (0.42\%). While, based on membrane performance and process efficiency when compared to $\mathrm{N}$-amino in retentate and permeate, $0.15 \mu \mathrm{m}$ MF membrane fitted in SMFC were able to separate $\mathrm{N}$-amino in retentates of soybeans tempeh from $5.56 \mathrm{mg} / \mathrm{mL}$ to $4.34 \mathrm{mg} / \mathrm{mL}$ (78\%), mung beans tempeh from $6.72 \mathrm{mg} / \mathrm{mL}$ to $3.36 \mathrm{mg} / \mathrm{mL}$ (50\%), and kidney beans tempeh from $0.84 \mathrm{mg} / \mathrm{mL}$ to $0.56 \mathrm{mg} / \mathrm{mL}$ (66.7\%), respectively.

\section{Dissolved protein}

The purification process of tempeh extract through $0.15 \mu \mathrm{m}$ MF membrane indicated successfully separation of dissolved protein, in which dissolved protein was retained more much in retentate when compared to pass it in permeate for the whole tempeh type. Dissolved protein is soluble peptides in water produced from the fermentation process of initial material involving natural enzymatic reactions, in which folic acid is possibility linked by PABA and pteridine. Dissolved peptides have a particle size ranging $0.01-0.1 \mu \mathrm{m}$ [14] so that they enter much more in permeate, except occurrence fouling. Based on recovery of $\mathrm{N}$-amino, 0.15 $\mu \mathrm{m}$ MF membrane fitted in SMFC method was able to raise dissolved protein in retentates of soybeans tempeh (101.28\% or 1.1 folds), mung beans tempeh ( $45 \%$ or 0.45 folds), and kidney beans tempeh ( $94.73 \%$ or 0.95 folds), respectively when compared to dissolved protein in feeds of soybeans tempeh ( $0.78 \%)$, mung beans tempeh $(0.34 \%)$, and kidney beans tempeh $(0.76 \%)$, respectively. Whereas, based on membrane performance and process efficiency when compared to dissolved protein in retentate and permeate, $0.15 \mu \mathrm{m}$ MF membrane fitted in SMFC method was able to separate dissolved protein in retentates of soybeans tempeh $(1.1 \mathrm{mg} / \mathrm{mL})$, mung beans tempeh $(0.63 \mathrm{mg} / \mathrm{mL})$, and kidney beans tempeh $(1.12 \mathrm{mg} / \mathrm{mL})$, respectively, and dissolved protein in permeates of soybeans tempeh $(0.79 \mathrm{mg} / \mathrm{mL})$, mung beans tempeh $(0.34 \mathrm{mg} / \mathrm{mL})$, and kidney beans tempeh $(0.72 \mathrm{mg} / \mathrm{mL})$, respectively.

From the whole purification processes on soybeans tempeh, mung beans tempeh and kidney beans tempeh extracts through $0.15 \mu \mathrm{m}$ MF membrane equipped in SMFC method with stirrer rotation speed $400 \mathrm{rpm}$, room temperature and pressure 40 Psi for 30 min were technically suitable to separate and recovery folic acid in retentate for soybeans tempeh (64.76\%), mung beans tempeh (43.85\%), and kidney beans tempeh (67.57\%), respectively. Total solids in retentate for soybeans tempeh (80\%), mung beans tempeh (61.8\%), and kidney beans tempeh (79\%), respectively. $\mathrm{N}$-amino in retentate for soybeans tempeh (78\%), mung beans tempeh (50\%), and kidney beans tempeh (66.7\%), respectively. Dissolved protein in retentate for soybeans tempeh (71.8\%), mung beans tempeh (54\%), and kidney beans tempeh (64\%), respectively. Based on MF membrane performance, MF optimization for the best purification 

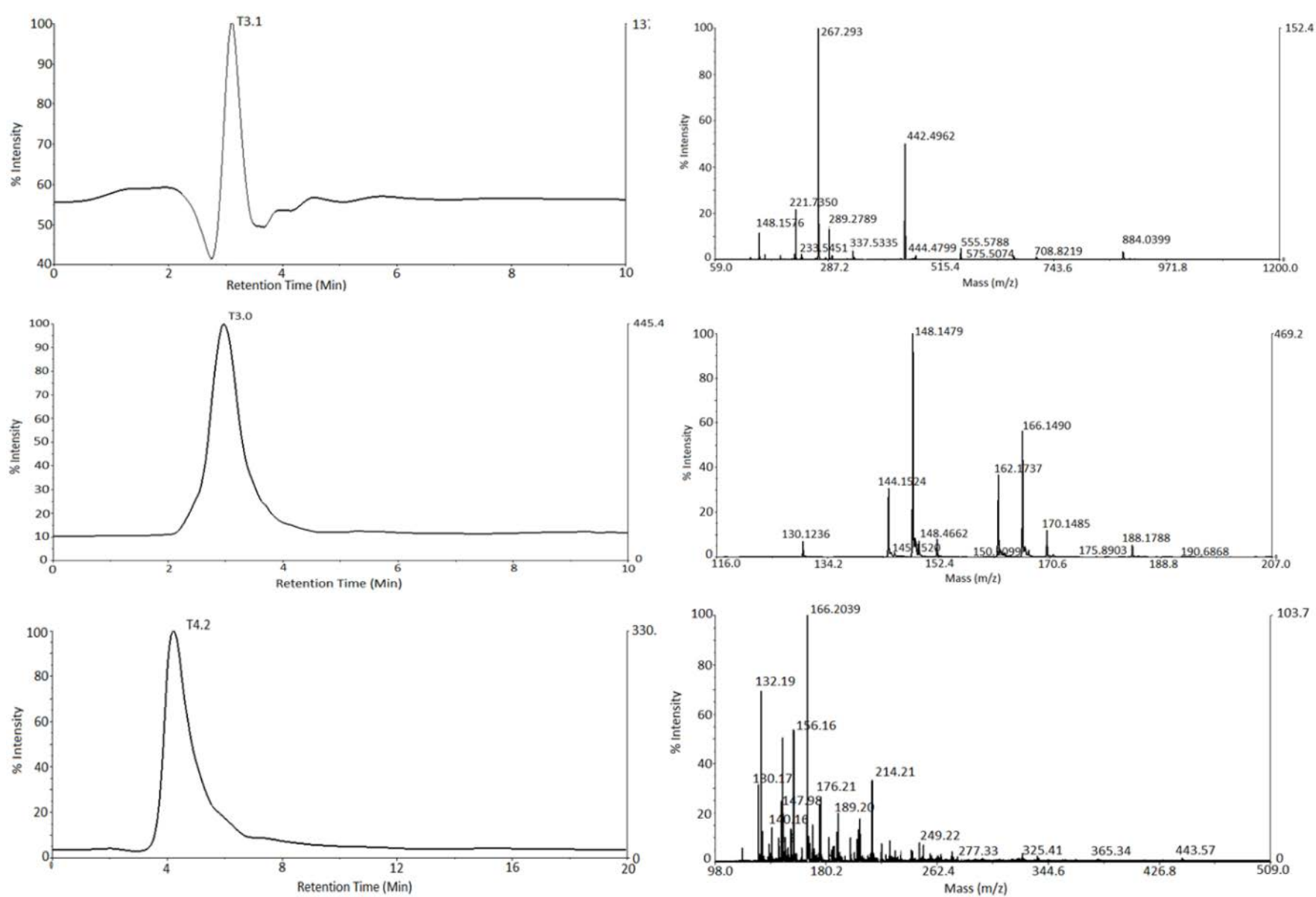

Fig 4. (a) Chromatogram of standard folic acid and (b) mass spectra (T3.1) of standard folic acid, (c) chromatogram of standard glutamic acid and (d) mass spectra (T3.0) of standard glutamic acid, (e) chromatogram of kidney beans tempeh extract and (f) mass spectra (T4.2) of kidney beans tempeh extract

Table 2. Data of dominant compounds on mass spectra of standard folic acid

\begin{tabular}{ccrrrrrr}
\hline Index & $\begin{array}{c}\text { Centroid } \\
\text { Mass }\end{array}$ & $\begin{array}{c}\text { Relative } \\
\text { Intensity }\end{array}$ & Area & Index & Centroid Mass & $\begin{array}{c}\text { Relative } \\
\text { Intensity }\end{array}$ & Area \\
\hline 1 & 148.157631 & 11.37 & 95.19 & 18 & 267.292185 & 100.00 & 1025.63 \\
2 & 148.546075 & 1.34 & 15.39 & 19 & 268.291245 & 15.71 & 89.71 \\
13 & 221.734988 & 21.69 & 177.84 & 20 & 268.762981 & 2.31 & 21.73 \\
16 & 233.245128 & 2.27 & 13.33 & 21 & 289.278878 & 13.14 & 104.16 \\
24 & 337.355276 & 3.65 & 48.30 & 25 & 362.762248 & 0.05 & 149.77 \\
26 & 442.496215 & 50.55 & 631.03 & 27 & 443.166533 & 8.35 & 24.35 \\
28 & 443.509427 & 14.98 & 60.46 & 29 & 444.479853 & 2.44 & 78.59 \\
30 & 464.491583 & 1.51 & 32.32 & & & & \\
\hline
\end{tabular}

process was reached by feed type of kidney beans tempeh extract as a result of pulverizing at a 1:2 ratio of kidney beans tempeh extract to water, type of retentate from protein isolate of soybeans tempeh, and type of permeate from protein isolate of soybeans tempeh.

\section{Identification of Monomer of Protein Isolate In} Kidney Beans Tempeh

Identification of standard folic acid is reached 1 peak (T3.1) with retention time $0-10 \mathrm{~min}$ and relative intensity $100 \%$, as shown in Fig. 4a. Mass spectra m/z 
69-1200 from T3.1 displayed compound domination with MW 267.29 Da. and relative intensity $100 \%$, while other monomers predicted as folic acid degrades by LC-MS system, as shown in Table 2 and Fig. 4b. Folic acid with MW $441 \mathrm{Da}$. [15] is shown with relative intensity $77 \%$, whereas compounds as a breakdown result of folic acid are glutamic acid, tetrahydroxy folic, etc. are a possibility the whole dominant compounds with MW range of 148.15-444.49 Da.

Identification of standard glutamic acid is yielded 1 peak (T3.0) with retention time $0-10 \mathrm{~min}$ and relative intensity $100 \%$, in which mass spectra $\mathrm{m} / \mathrm{z}$ 111-784 from T 3.0 demonstrated compound domination with MW 148.14 Da. and relative intensity 100\%, as shown in Fig. $4 \mathrm{c}$ and $4 \mathrm{~d}$. Its presence of glutamic acid was indicated by the assumption that glutamic acid was a part of folic acid. Through LC-MS instrument had been shown that a compound showed possibility a difference in $\mathrm{MW}$, in which it probably are as $\mathrm{M}^{+}, \mathrm{M}^{+}, \mathrm{Na}^{+}, 2 \mathrm{M}^{++}$or $2 \mathrm{M}^{+}+\mathrm{Na}^{+}$. This matter is caused by ionization because of sensitivities of LC-MS instrument relating with eluent used. Operation condition of LC-MS is injection volume of $2 \mu \mathrm{L}$, flow rate $0.05 \mathrm{~mL} / \mathrm{min}$ with eluent mixture of methanol and water (contains $0.3 \%$ Acetic acid)) at ratio 80:20, using C-18 (15 mm x $1 \mathrm{~mm}$ ) column [11].

Identification of monomer of protein isolate in kidney beans tempeh showed that it is reached 1 peak, namely T4.2 with retention time $0-20 \mathrm{~min}$ with relative intensity $100 \%$, as showed in Fig. 4e. Mass spectra m/z 135-270 from T4.0 showed domination of glutamic acid with MWs of 145.22, 146.21, 147.20, 147.57, 148.16, 148.51 , and $149.16 \mathrm{Da}$. and relative intensities of 9.25 , $1.48,24.44,2.43,50.11,3.48$ and $3.76 \%$, respectively or the optimum glutamic acid has possibility MW of 148.16 with intensity $50.11 \%$. While folic acid monomer has MW of 443.57 and $444.53 \mathrm{Da}$. with intensity 1.28 and $0.68 \%$ or the optimum folic acid has possibility MW of 443.58 with intensity $1.28 \%$. Monomer as a breakdown of folic acid is suitable to compound type at standard folic acid with MW range of 220.28-337.37 Da. and relative intensity range of $0.68-1.4 \%$ or as a breakdown of the optimum folic acid has possibility MW of 221.21 with intensity 7.05\%, as displayed in Table 3 and Fig. 4 f. Folic acid concentration reached is very low $(\mu \mathrm{g} / \mathrm{mL})$, as identification through LC-MS.

Table 3. Data of mass spectra of standard glutamic acid

\begin{tabular}{cccrcccr}
\hline Index & $\begin{array}{c}\text { Centroid } \\
\text { Mass }\end{array}$ & $\begin{array}{c}\text { Relative } \\
\text { Intensity }\end{array}$ & Area & Index & Centroid Mass & $\begin{array}{c}\text { Relative } \\
\text { Intensity }\end{array}$ & Area \\
\hline 2 & 144.152369 & 30.59 & 775.88 & 5 & 148.466240 & 8.51 & 56.76 \\
3 & 145.152683 & 2.06 & 40.60 & 6 & 149.145287 & 7.06 & 165.60 \\
4 & 148.147897 & 100.00 & 2542.26 & & & & \\
\hline
\end{tabular}

Table 4. Data of dominant compounds on mass spectra of kidney bean tempeh exstract

\begin{tabular}{rcrrrrrr}
\hline Index & $\begin{array}{c}\text { Centroid } \\
\text { Mass }\end{array}$ & $\begin{array}{c}\text { Relative } \\
\text { Intensity }\end{array}$ & Area & Index & Centroid Mass & $\begin{array}{c}\text { Relative } \\
\text { Intensity }\end{array}$ & Area \\
\hline 14 & 145.226413 & 9.25 & 56.65 & 116 & 265.236515 & 2.78 & 23.33 \\
15 & 146.209329 & 1.48 & 9.08 & 117 & 268.223228 & 0.71 & 8.44 \\
16 & 147.198835 & 24.44 & 158.04 & 123 & 280.304769 & 0.70 & 8.80 \\
17 & 147.572325 & 2.43 & 13.87 & 124 & 290.333602 & 0.78 & 7.92 \\
18 & 148.164316 & 50.11 & 288.25 & 135 & 337.376226 & 1.22 & 9.27 \\
19 & 148.510734 & 3.48 & 22.95 & 95 & 232.268334 & 1.40 & 15.78 \\
20 & 149.163033 & 3.76 & 23.74 & 96 & 233.278327 & 1.81 & 11.61 \\
87 & 220.284618 & 0.68 & 7.93 & 97 & 235.270424 & 3.78 & 38.70 \\
88 & 221.213238 & 7.05 & 47.72 & 139 & 443.579722 & 1.28 & 11.50 \\
89 & 224.38414 & 2.62 & 20.87 & 140 & 444.535962 & 0.68 & 7.31 \\
94 & 231.248346 & 4.24 & 35.69 & & & & \\
\hline
\end{tabular}

Aspiyanto et al. 


\section{- CONCLUSION}

The interaction between types of tempeh and membrane performance effects on separation of components in tempeh protein isolate. Components in tempeh protein isolate retained in retentate were more much that passing in permeate. Stirred Microfiltration Cell (SMFC) is able to recover soybean, mung bean, and kidney bean tempeh isolates. They contain folic acid $64.76,43.85$ and $67.57 \%$, total solids $80,61.8$ and $79 \%, \mathrm{~N}$ amino 78, 50 and $66.7 \%$, and dissolved protein $71.8,54$ and $64 \%$, respectively. Retentates from soybean, mung bean, and kidney bean tempeh protein isolates contain folic acid of 362.07, 254.07 and 506.07 $\mu \mathrm{g} / \mathrm{mL}$, total solids of 5.56, 4.08 and $1.82 \%, \mathrm{~N}$-amino of $4.34,3.36$ and 0.56 $\mathrm{mg} / \mathrm{mL}$, and dissolved protein of $0.79,0.34$ and 0.72 $\mathrm{mg} / \mathrm{mL}$. In these conditions, SMFC were able to increase folic acid in retentates of soybeans 59.67\% (0.59 folds), mung beans $110.58 \%$ ( 1.1 folds) and kidney beans $142.67 \%$ (1.42 folds) prior to purifying (feed) or optimization was reached by kidney bean tempeh. Identification of kidney bean tempeh protein isolates generated monomer of folic acid 443.57, 148.16 and $221.21 \mathrm{Da}$. with relative intensities of $1.28,50.11$ and $7.05 \%$.

\section{- REFERENCES}

[1] Nugraha, T., Susilowati, A., Aspiyanto, Lotulung P.D., and Maryati, Y., 2017, Characterization of biomasses, concentrates, and permeates of dried powder of Kombucha fermentation of spinach (amaranthus sp.) and broccoli (brassica oleracea) with membrane microfiltration and freeze drying techniques for natural sources of folic acid, AIP Conf. Proc., 1904, 020023.

[2] Tamime, A.Y., 2013, Membrane Processing: Dairy and Beverage Applications, Wiley-Blackwell, 370.

[3] Kumar, P., Sharma, N., Ranjan, R., Kumar, S., Bhat, Z.F., and Jeong, D.K., 2013, Perspective of membrane technology in dairy industry: A review, Asian Australas. J. Anim. Sci., 26 (9), 1347-358.

[4] Jegatheesan, V., Shu, L., Keir, G., and Phong, D.D., 2012, Evaluating membrane technology for clarification of sugarcane juice, Rev. Environ. Sci. Biotechnol., 11 (2), 109-124.

[5] Aspiyanto, Susilowati, A., Iskandar, Y.M., and Maryati, Y., 2009, Potential use of microfiltration membrane in separation of amino acids as savory fraction from extract of vegetable broth of mung beans (Phaseolus radiatus 1.) through brine fermentation by Aspergillus sp-K3 and Rhizopus$\mathrm{C}_{1}$, J. Appl. Ind. Biotechnol. Trop. Reg., 2 (1), 1-7 (Special Edition).

[6] Rao, L., Hayat, K., Lv, L., Karangwa, E., Xia, S., and Jia, C.S., 2011, Effect of ultrafiltration and fining adsorbents on the clarification of green tea, J. Food Eng., 102 (4), 321-326.

[7] Ghosh, R., 2003, "Ultrafiltration: An overview" in Protein Bioseparation Using Ultrafiltration: Theory, Applications and New Developments, Imperial College Press, London, UK, 13-15.

[8] AOAC, 2016, Official Methods of Analysis, Association of Official Analytical Chemists International, $20^{\text {th }}$ Ed., Washington D.C.

[9] Pope, C.G., and Stevens M.F., 1939, The determination of amino nitrogen using copper method, Biochem. J., 33 (7), 1070-1077.

[10] Ruengsitagoon, W., and Hattanat, N., 2012, Simple spectrophotometric method for determination offolic acid, The $4^{\text {th }}$ Annual Northeast Pharmacy Research Conference "Pharmacy Profession in Harmony", Faculty of Pharmaceutical Sciences, Khon Kaen University, Thailand, 11-12 February 2012, 281.

[11] Eichhorn, P., and Knepper, T.P., 2001, Electrospray ionization mass spectrometric studies on the amphoteric surfactant cocamido propylbetaine, $J$. Mass Spectrom., 36 (6), 677-684.

[12] Susilowati, A., Iskandar, J.M., Melanie, H., Maryati, Y., Lotulung, P.D., and Aryani, D.G., 2015, Pengembangan konsentrat sayuran hijau dan kacang-kacangan terfermentasi pada jagung (Zea mays L.) pramasak sebagai sumber asam folat untuk formula pangan pintar, Research Report, Research Center for Chemistry - Indonesian Institute of Sciences. 
[13] Anonymous, 2008, Catalogue and Manual of Stirred Ultrafiltration Cells, Amicon Bioseparations, MILLIPORE, U.S.A.

[14] Susilowati, A., Aspiyanto and Melanie, H., 2017, Characterization of fermented broccoli (Brassica oleracea L.) and spinach (Amaranthus sp.) produced using microfiltration membrane as folic acid source for smart food formula, MATEC Web Conf., 101, 01005. 